\title{
JAPANESE IMMIGRANTS IN SARAWAK BEFORE WORLD WAR TWO: ASSIMILATION THROUGH INTER- ETHNIC MARRIAGES ${ }^{1}$
}

\author{
Md Nasrudin Md Akhir, ${ }^{2}$ Geetha Govindasamy ${ }^{3}$, and Rohayati Paidi ${ }^{4}$
}

\begin{abstract}
The arrival of Japanese immigrants, especially karayuki-san, traders, and farmers in Sarawak between the 1880s and1940s, has rarely been given sufficient attention by scholars. For the most part, not only did the Japanese immigrants successfully integrate into the economic eco-system, but they also assimilated with the locals through inter-marriages. Archival records, primarily obtained from the Sarawak State Archives, suggests that families of inter-ethnic marriages went through a life of hardship, especially when Japanese spouses or relatives were imprisoned in the internment camps soon after World War Two ended. For the most part, the research mainly focuses on Seiji Kuno or otherwise known as Mohamed Towpik Kuno, who married a local Malay woman and embraced Islam. The life of Kuno depicts the extent to which a Japanese immigrant became absorbed into the dominant culture of the mainstream Sarawak society. Kuno's general attitude towards the local society, his service to the community in various capacities, his attitude towards political matters and finally, his religious inclination showcased the extent to which assimilation had taken place voluntarily. Apart from Kuno, the research also examines other personalities' lives, like Sunao Miyaji, who was married to Lamah Binti Bakar, and Maria Osaichi and Oasa, who were Japanese immigrants married to Chinese Sarawakians. It is against this background that this research argues that marriages between Japanese immigrants and locals in Sarawak before World War Two was indeed a cause for further assimilation into the host culture between spouses, family members and the broader community. At the same time, the research posits that cemeteries involving Japanese immigrants should be promoted as tourist destinations as they reflect Sarawak's rich multicultural heritage and history of assimilation with foreigners.
\end{abstract}

Keywords: assimilation, Japanese detainees, Sarawak, multiculturalism

\footnotetext{
${ }^{1}$ Article info: Received: 27 September 2021; Acceptance: 28 October 2021; Published: 15 December 2021.

${ }^{2}$ First and Corresponding Author: Associate Professor Dr. Md. Nasrudin Md. Akhir, Department of East Asian Studies, Faculty of Arts and Social Sciences, University of Malaya, Kuala Lumpur 50603, Malaysia. He is a former Director, founder and currently served as an Associate Researcher at the Malaysian Japan Research Centre (MJRC), University of Malaya. Email: mnasrudi@um.edu.my

${ }^{3}$ Second Author: Dr. Geetha Govindasamy, Senior Lecturer, Department of East Asian Studies, Faculty of Arts and Social Sciences, University of Malaya, Kuala Lumpur 50603, Malaysia. She is also currently served as an Associate Researcher at Malaysian Japan Research Centre (MJRC), University of Malaya. Email: geethag@um.edu.my

${ }^{4}$ Third Author: Dr. Rohayati Paidi, Senior Lecture and Head of the Department of East Asian Studies, Faculty of Arts and Social Sciences, University of Malaya, Kuala Lumpur 50603, Malaysia. She is also currently served as an Associate Researcher at Malaysian Japan Research Centre (MJRC), University of Malaya. Email: rohayatipaidi@um.edu.my
} 


\section{JAPANESE COMMUNITY IN SARAWAK BEFORE WORLD WAR TWO}

Sarawak was an key locale for Japanese settlers operating under the encouragement of the Brooke government (1841-1946). The Japanese in Sarawak arrived parallel to that of Japanese migration into British Malaya shortly after the onset of the Meiji Restoration (1868). A small but economically and socially active community, the Japanese mostly arrived during the period of the Brooke Rajahs where they made their mark by working and sustaining a livelihood till the day they died. ${ }^{5}$ Since the early Meiji period in 1880 s, in addition to arriving voluntarily to find a new economic opportunities (dekasegi-nin), more often than not, unemployed individuals were cheated by agents or kidnapped and smuggled out of Japan without proper documents into various parts of Southeast Asia. ${ }^{6}$ The earliest documentary reference of Japanese presence in Sarawak was in $1889 .{ }^{7}$ The first group hailed from Okinawa, followed subsequently by immigrants from Nagasaki, Fukuoka and other prefectures close to the sea coast, of whom, later became fishermen and farmers. ${ }^{8}$ As was the case in British Malaya ${ }^{9}$, the majority of the early Japanese inhabitants in Sarawak were mostly prostitutes or commonly referred to as karayuki-san. The karayuki-san originated from economically marginalized families from the rural and poorer southwestern area of Kyushu. ${ }^{10}$ This is evidenced by the existence of gravestones of these women in Sarawak's Batu Lintang's Japanese cemetery. Some of the gravestones which originated as early as from the Meiji period provides evidence of the early origins of the Japanese in the state. ${ }^{11}$ Accompanying Shozo Yorioka ${ }^{12}$ on his visit to Sarawak in 1910, Kiichi Hayashi was dismayed to find that his country was being represented largely by karayuki-san. ${ }^{13} \mathrm{He}$ further added that,

There are about 60 Japanese here. About 20 of them are men and 40 women. I was surprised to find that most of them engage in the disreputable occupation of prostitution and other employment related to it. It is unbearable to see these fellow countrymen selling their bodies and souls and thus bringing disgrace on our country, which has emerged as a rising nation creating attention from all over the world. ${ }^{14}$

Apart from the karayuki-san, Shozo Yorioka's arrival indicated that there were many who came to Sarawak voluntarily to seek new opportunities. According to Ooi Keat Gin, between 1800s and 1900s,

\footnotetext{
${ }^{5}$ John M. Chin, “The Japanese Community Cemetery in Kuching,” Sarawak Gazette 121, no. 1527, (1994): 21.

${ }^{6}$ Ooi Keat Gin, The Japanese Occupation of Borneo, 1941-1945, (London: Routledge, 2011), 11.

${ }^{7}$ Craig Alan Lockard, From Kampung to City: A Social History of Kuching Malaysia, 1820-1970, (Athens, Ohio: Ohio University Press, 1987), 38.

${ }^{8}$ John M. Chin, "The Japanese Community Cemetery in Kuching," (1994): 21-22.

${ }^{9}$ Md Nasrudin Md Akhir dan Tsuji Shyuji, “Aktiviti Ekonomi dan Pertubuhan Orang Jepun di Selangor, 1881-1931," dalam Rohayati Paidi, Asmadi Hassan, dan Md Nasrudin Md Akhir eds., Jepun dan Dinamisme Global, (Kuala Lumpur: UM Press, 2019), 3-10.

10 John M. Chin, "The Japanese Community Cemetery in Kuching," (1994): 23.

${ }^{11}$ Ibid., (1994): 23.

${ }^{12}$ Yorioka Shozo arrived in Kuching in October 1910 to seek 10,000 acres to plant rubber, sweet potato, coconut and other crops. An employee of Suzuki Shoten, Shozo Yorioka was sponsored by Naokichi Kaneko and Samata Sakuma, the Governor-general of Taiwan, whom he met through his brother. Shozo Yorioka applied to the Sarawak government to lease 10,000 acres and waited for a response from Rajah Brooke who was then in England. Unfortunately, by the time a 99-year lease of 1,700 acres was approved in December 1911, Shozo Yorioka had died of malaria in Kyoto at the age of 47. His younger brother, Shosuke took over and formed Nissa Shokai Kabushiki Kaisha in order to pursue the project. Under his direction, two further 1,000 acres leases were obtained from the government between 1913 and 1918.

${ }^{13}$ Bob Reece, Masa Jepun: Sarawak under the Japanese 1941-1945, (Kuala Lumpur: Sarawak Literacy Society, 1998), 12.

${ }^{14}$ Bob Reece, Masa Jepun: Sarawak under the Japanese 1941-1945, (1998), 12.
} 
many Japanese were petty traders, barbers, dentists, physicians, hairdressers, masseurs and rubber plantation owners. ${ }^{15}$ Later, others were involved in more commercial enterprises. Shozo Yorioka was the founder of Nissa Shokai, a trading company specializing in Japanese goods established in the early of the 20th century. In the 1900s, Japan became a first-class imperial power, perceived to be at par with other westerns powers like that of Britain, France and the United States. With World War One raging in the European continent, Southeast Asia faced a shortage of western goods, making it easier for Japanese products to be exported to the region. Seizing this opportunity many Japanese men disengaged themselves from prostitution and began legitimate businesses such as opening grocery stores that sold inexpensive Japanese originated goods to local consumers. ${ }^{16}$ This was the case for men like Kiichi Hayashi who migrated to Sarawak merely to start a business. ${ }^{17}$ Some others settled in the vicinity of Kuching, being employed in commerce or on rubber estates. ${ }^{18}$ There were also Japanese professionals like Dr. Nakagawa, a dentist in Kuching. ${ }^{19}$ The Iwanaga sisters, whose dentist father had died some years earlier, were teachers at Kuching's St. Mary's School. As K. H. Digby, the acting legal advisor to the government observed, the Brooke administration welcomed foreign investors in developing the state. ${ }^{20}$ Digby highlighted that the biggest number of Japanese in Sarawak lived on the Nissa Shokai estate, located on the banks of the Samarahan river. A number of families involved in the estate lived there. It was reported that twelve persons held executive posts. A resident doctor was employed to live on the estate. The estate was made up of one hundred acres of wet padi and a large area for pineapple plantation, but most of the land remained a rubber plantation. The estate had a bazaar and police-station, patrolled by one government lance-corporal and four constables. ${ }^{21}$ It was reported that between 1929-1932, Nissa Shokai conducted coal exploration in the Iran (Long Hills) area in Sarawak. $^{22}$ An informal agent for Nissa Shokai, the most famous Japanese woman at that time in Kuching was Madam Nakako Ogawa who had married Edward Parnell in the early 1920s. Parnell was the Managing Director of the Sarawak Steamship Company. ${ }^{23}$ Gradually, Japanese led social clubs began to emerge for the community to converge.

In Miri, the Japanese community included a dentist, prostitutes who ran small businesses and some washerwomen. All in all, in pre-war days, according to a 1935 census conducted by the Japanese government, it was estimated that a total of 136 Japanese nationals were living in Kuching and Miri. Forty-nine Japanese families lived in the Kuching area and seven in the Miri. ${ }^{24}$ While many associations were established, approaching World War Two, two key associations were established which were the Japanese Association which was formed in 1937 and the Japanese social club in 1941 at Tabuan Road in Kuching. ${ }^{25}$ By 1939, with Sarawak economy growing, there were 155 Japanese nationals in Sarawak. ${ }^{26}$

The growing Japanese maintained relatively good relations with the local community and government. In urban areas, it was common to see Japanese court the Malays; some even converted

\footnotetext{
${ }^{15}$ Ooi Keat Gin, The Japanese Occupation of Borneo, 1941-1945, (2011), 19-20.

${ }^{16}$ Ooi Keat Gin, The Japanese Occupation of Borneo, 1941-1945, (2011), 13.

${ }^{17}$ Bob Reece, Masa Jepun: Sarawak under the Japanese 1941-1945, (1998), 12.

${ }^{18}$ Hara Fujio, “Japanese Activities in North Borneo Before World War II: Focus on Labour Immigrants," Sejarah: Journal of the Department of History 29, no. 2, (I993): 127.

${ }^{19}$ Ah Chon Ho, Kuching in Pictures, 1841-1946, (Kuching: See Hua Daily News Bhd., 1965), 146.

${ }^{20}$ Amarjit Kaur, "The Babbling Brookes: Economic Change in Sarawak 1841-1941," Modern Asian Studies 29, no. 1, (I995): 91.

${ }^{21}$ K. H. Digby, Lawyer in the Wilderness, (New York: Cornell University, 1980): 33.

${ }^{22}$ Chen Shick Pei, "Coal Potential and Exploration in Sarawak," Bulletin of the Geological Society of Malaysia 20 , no. August, (1986): 662.

${ }^{23}$ Bob Reece, Masa Jepun: Sarawak under the Japanese 1941-1945, (1998), 11.

${ }^{24}$ Ibid., 11.

${ }^{25}$ Ibid., 11.

${ }^{26}$ J. L. Noakes, Sarawak and Brunei: A Report on the 1947 Population Census, (Kuching: Government Printing Press, 1950), 35-40.
} 
and married Muslim Malay women. ${ }^{27}$ It has to be noted that though there were many cases of inter marriages between Japanese immigrants and locals but only selected cases will be examined in this research. Lack of archival or documented evidence has restrained the researchers to only concentrate on cases that reflected inter-ethnic marriages that have been documented in the National Archives of Sarawak.

\section{ASSIMILATION THEORY}

In the course of interactions with the locals, the Japanese community adapted well to new social and economic characteristics. They acclimatized to values, beliefs, and customs by assimilating into the mainstream Sarawak society. Before embarking on explanations on how the Japanese in Sarawak assimilated, it is pertinent to understand what assimilation means. Generally an immigrant is considered fully assimilated when he or she is able to speak the local language and participate in social rituals of the community unimpeded by prejudices. ${ }^{28}$ This assimilation process includes several steps whereby immigrants fully embrace the cultural patterns of the native community, network socially with the locals in various capacities, intermarry, develop a local identity and immerse themselves into the society till they don't encounter prejudices or power conflict with the natives. ${ }^{29}$

One of the most recognized indicators of assimilation is inter-ethnic marriages that take place when immigrants marry with native born spouses. ${ }^{30}$ According to Qian and Lichter, inter marriages are noteworthy as they directly impact on immigrant adaptation and acculturation. ${ }^{31}$ It cannot be denied that sometimes, immigrants are likely to marry out of their community due to the shortage of potential spouses from their own immigrant group. Yet this does not revoke the impact of inter-ethnic marriages as a factor that contributes to furthering the assimilation process. Similarly, Marcson claims, 'amalgamation, or the crossing of racial and ethnic traits through inter marriage also promotes assimilation.' ${ }^{32}$ Therefore, this article adopts Price and Zubrzycki's ethnic assimilation definition which is,

Assimilation" covers not only integration but economic absorption, social acculturation, and physical amalgamation; it may also refer to a final stage wherein the immigrant stock becomes completely indistinguishable from other stock. ${ }^{33}$

The next section examines the lives of some Japanese civilian internees at Bau Detention Camp in Sarawak. The data for individuals concerned is derived from archival sources obtained in Sarawak. By examining the background of these internees, the research aims to show the degree to which some Japanese assimilated through contact and communication and became part and parcel of the larger dominant Sarawak population. In particular, the research aims to highlight how inter-ethnic marriages became the agent of assimilation. It is against this background that the research will feature the extent to which some Japanese immigrants in Sarawak transformed their socioeconomic achievements into residential and marital assimilation.

${ }^{27}$ Ooi Keat Gin, Rising Sun Over Borneo: The Japanese Occupation of Sarawak, 1941-1945, (London: Macmillan Press Ltd., 1999), 21.

${ }^{28}$ Milton M. Gordon, Assimilation in American Life: The Role of Race, Religion, and National Origins, (New York: Oxford University Press, 1964), 115.

${ }^{29}$ Milton M. Gordon, Assimilation in American Life: The Role of Race, Religion, and National Origins, (1964), 116.

${ }^{30}$ Darrel Montero, “The Japanese Americans: Changing Patterns of Assimilation Over Three Generations," American Sociological Review 46, no. 6, (1981): 829-839.

${ }^{31}$ Zhenchao Qian and Daniel T. Lichter, "Social Boundaries and Marital Assimilation: Interpreting Trends in Racial and Ethnic Intermarriage," American Sociological Review 72, no. 1, (2007): 68-94.

${ }^{32}$ Simon Marcson, “A Theory of Intermarriage and Assimilation,” Social Forces 29, no. 1 (1950): 75-78.

${ }^{33}$ C. A. Price and J. Zubrzycki, "The Use of Inter-Marriage Statistics as an Index of Assimilation," Population Studies 16, no. 1 (1962): 58-69. 


\section{SELECTED JAPANESE CIVILIAN'S INTERNEES AT BAU DETENTION CAMP WHO MARRIED SARAWAKIANS}

Between September 1945 and January1946, Sarawak was administered by the Australian Imperial force (AIF) under the direct administration of the British Borneo Civil Affairs Unit (BBCAU). The subject of Japanese internees in Sarawak after the surrender of the Japanese Imperial Army by BBCAU has been overlooked when studying British held prisoners in Borneo. As such, the next section aims to underscore the experiences of families of Japanese internees of whom many married local women.

\section{The case of Seiji Kuno}

Seiji Kuno, a Japanese national was believed to have arrived in Sarawak around 1909 or 1910. He was reportedly a former employee of Nissa Shokai. ${ }^{34}$ Seiji Kuno who was known by several names - Mohd Tawfek or Mohamed Towpik Kuno or Mohd Jepun, owned a shop in India Street in Kuching. Reportedly, he was an acupuncturist and herbalist. Kuno married Ejah binti Haji Rais when she was 18 years old, on 12 June 1917 and had 7 children. ${ }^{35}$ Prior to his marriage, Kuno had already converted to Islam. ${ }^{36}$ Having immersed himself with the local community, he eventually became the Tua Kampung (village head) of Senyawau, located in Samarahan, for about 17 years. ${ }^{37}$

As in all wars, following the surrender of Japan in August 1945, Japanese civilians like Kuno were arrested and put in a detention center as internees. ${ }^{38}$ During the Japanese occupation, Kuno was an interpreter working in various departments such as in the police force and the courts. However, Kuno was not an officer of the Kampetai or charged as War Criminal but was viewed as an ordinary civilian. ${ }^{39}$ Regardless, Kuno was still detained.

The following is a timeline of Kuno's family's experiences while he remained a detainee. At the time of his arrest, Kuno's son Spawi was 29; Zaini aged 21 (unmarried and working with Sarawak state as a teacher); and Borhan aged 16 (unmarried). His daughters included Taiwa aged 19 (married to Gani); Yok aged 15 (unmarried); Mardiah 10 and Dayang who was 3 years old. On 29 October 1945, Kuno's wife Ejah binti Haji Rais was granted permission to visit Kuno. ${ }^{40}$ On 1 November, 1945, Major T.A.Rodriquez from the British Military HQ Kuching Force gave the permission to Ejah to visit her husband who was detained at the Lintang Barracks. ${ }^{41}$ The visit was fixed on 4 November 1945 and her daughter and son-in-law, Dayang and Gani, were allowed to accompany her. ${ }^{42}$ Again, on 24 December 1945, Ejah sent a letter to Lt. Col. W.P.N.L Ditmas regarding Kuno who was detained at Surrender Camp at Krokong, Bau district in Kuching. Once again on 30 January 1946, Ejah sent

\footnotetext{
${ }^{34}$ Bob Reece, Masa Jepun: Sarawak under the Japanese 1941-1945, (1998), 9.

35 BBCAU Adm. K/54, Textual Document, Pustaka Negeri Sarawak [Sarawak State Archive], Kuching, Sarawak, Malaysia.

${ }^{36}$ Correspondence from DET BBCAU Kuching sent to HQ Force Kuching, 12 October 1945, BBCAU Adm. K/54, Pustaka Negeri Sarawak [Sarawak State Archive], Kuching, Sarawak, Malaysia.

${ }^{37}$ Correspondence from DET BBCAU Kuching sent to HQ Force Kuching, 29 October 1945, Pustaka Negeri Sarawak [Sarawak State Archive], Kuching, Sarawak, Malaysia.

${ }^{38}$ Correspondence from Major T. A. Rodriquez, BM Kuching Force, Pustaka Negeri Sarawak [Sarawak State Archive], Kuching, Sarawak, Malaysia.

${ }^{39}$ BBCAU Adm. K/54, 11 January 1946, Textual Document, Pustaka Negeri Sarawak [Sarawak State Archive], Kuching, Sarawak, Malaysia.

${ }^{40}$ Correspondence from Cao Det BBCAU Kuching to the HQ "K" Force Kuching, 29 October 1945, Pustaka Negeri Sarawak [Sarawak State Archive], Kuching, Sarawak, Malaysia.

${ }^{41}$ PA pass issued by Major T.A. Rodriquez to Ejah Binti Hj. Rais, 1 November 1945, Pustaka Negeri Sarawak [Sarawak State Archive], Kuching, Sarawak, Malaysia.

${ }^{42}$ Correspondence from Major T. A. Rodriquez, BM Kuching Force, 28 November 1945, Pustaka Negeri Sarawak [Sarawak State Archive], Kuching, Sarawak, Malaysia.
} 
another letter to Captain Morris enclosed with a copy of her letter dated 11 January 1946 to Lt. Col. W.P.N.L Ditmas on her petition for the release of Kuno, who was interned at Surrender Camp at Krokong, Bau district. Earlier, she was informed that all Japanese nationals in the Bau camp will be deported to Japan within two weeks' time. Ejah highlighted to the BMA that Kuno had lived in Sarawak for 35 years and at one time was elected as Tua Kampung of Seniawan in Samarahan. She made the case that her husband was well assimilated into the mainstream community. Using this reason, she requested the authorities to release her Japanese husband who was well respected by the local community. ${ }^{43}$ Unfortunately, lack of evidence makes it difficult to confirm if Ejah was actually allowed to visit her husband. More importantly, the status of Kuno himself has not been discovered to date.

As mentioned before, this research focuses more on the assimilation process rather than the history of Japanese detainees. Hence, the case of Mohamed Kuno is very noteworthy as he was well assimilated into the local community. On the instructions of his British superiors, Abang Openg as the Native Officer in Kuching at that time, was asked to obtain information and prepare a report on Kuno's conduct and activities during the Japanese occupation as well as a report from the current Tua Kampung. ${ }^{44}$ According to a confidential letter dated 27 November 1945, in order to investigate Kuno, Abang Openg sent a letter to six Datus including Datu Patinggi (Abang Haji Abdillah), Datu Hakim (Haji Mohidin), Datu Menteri (Zain Mohamad), Datu Amar (Abang Suleiman), Datu Pahlawan (Abang Haji Mustapha), Datu Temenggong (Abang Kipali) and one Tua Kampung (Mohd Dol bin Osman). Abang Openg wanted information on Kuno's attitude towards the general public, details of his shares in political matters, details of any assistance which he rendered the general public, facts regarding his religious inclination and any additional information. ${ }^{45}$ On 17 December 1945, Abang Openg passed a comprehensive report of Kuno to Captain Morris, CAO Detention BBCAU Kuching based on information from the Datus and Tua Kampung regarding Kuno's conduct during the Japanese occupation. Abang Openg's report was devoid of Datu Menteri's input as the gentleman had no contact with Kuno. ${ }^{46}$

What is interesting about Abang Openg's report is that Kuno's assimilation process into the Sarawak society was very rapid due to his personality and actions during the Japanese occupation of Sarawak. Of course, the assimilation would not have taken place if he was not married to a local born spouse which helped him to be accepted by the community at large. Generally, the Datus and Tua Kampung had a positive view of Kuno's public persona. Kuno was famous for being the a Tua Kampung for 19 years. He was deemed not to have any particular political leanings and that he was merely an interpreter for Japanese officials. Most viewed Kuno as being very sociable and sincere. More importantly, he was known to assist the locals as well as protect local customs.

As an interpreter to Japanese officers, Kuno played a pivotal role of being a mediator between the local community and officials. Most of the interviewees also asserted that Kuno assisted the Japanese administration in dealing fairly where native cases in court proceedings were involved. In other words, as a long-term resident of Sarawak, Kuno knew how to deal with native feelings and customs and made it a point to fight behalf of them. Consequently, it was not surprising that Kuno aided in submitting petitions from the natives of Sarawak to the Japanese administration as a means of alleviating hardships faced by the locals. At one time in 1944, officials forced the members of the

\footnotetext{
${ }^{43}$ BBCAU Adm. K/54, 30 January 1946, Textual Document, Pustaka Negeri Sarawak [Sarawak State Archive], Kuching, Sarawak, Malaysia.

${ }^{44}$ Confidential document 44, BBCAU Adm. K/54, Textual Document, Pustaka Negeri Sarawak [Sarawak State Archive], Kuching, Sarawak, Malaysia.

${ }^{45}$ Correspondence from Abang Openg to 7 Datus, 27 November 1945, Confidential document 43, BBCAU Adm. K/54, Pustaka Negeri Sarawak [Sarawak State Archive], Kuching, Sarawak, Malaysia.

${ }^{46}$ Correspondence from Abang Openg to Captain Morris, 17 December 1945, Confidential document 56, BBCAU Adm. K/54, Pustaka Negeri Sarawak [Sarawak State Archive], Kuching, Sarawak, Malaysia.
} 
Ladies Union (which was formed by Japanese) to contribute their jewelries for the war effort. But after some negotiations, Kuno was successful in returning the jewelries to the respective members.

One of the key questions investigated by Abang Openg was Kuno's religious inclinations. According to the responses given, Kuno is said to be a devout Muslim who helped his fellow Muslims in the affairs of the mosque. Prior to the war, Kuno taught religious classes in Samarahan. He even assisted the Malays by obtaining support from the Japanese authorities to fund certain activities in the mosque. Eventually the authorities began providing $\$ 900$ annually for wages, grass cutting, feasting on important occasions like that of the birthday of prophet Mohammad as well as supporting expenses for entertainment during the fasting month. Overall, the interviewees' idea of Kuno is largely related to him being well assimilated in the local cultural eco system to the extent he was seen as a defender of Islam and the local community during the Japanese occupation period.

\section{The case of Sunao Miyaji}

Another Japanese civilian in Kuching by the name of Sunao Miyaji was also arrested at the detention camp however, after being referred to the BBCAU authority, C. E. Gascoigne depicted him as "not a bad egg". ${ }^{47}$ Sunao Miyaji was born in Kagoshima-ken in 1889 and he was the second son of Sumitaro Miyaji. Miyaji worked at the Yamashita Steamship Co. Ltd. in Japan. His last entrance to Sarawak printed in his passport was 10 October $1932 .{ }^{48}$ Although records are a little blur on Miyaji's first entrance into Sarawak, but it is believed he was engaged in trading. The official document carried by him was issued by Count Yasuya Uchida, Japanese Minister of Foreign Affairs which stated his journey to Hong Kong, Straits Settlements and British Borneo was related to commercial business. ${ }^{49}$ Like Kuno, Miyaji was married to a Malay Muslim woman by the name of Lamah binti Bakar in 1921. Archival documents indicate that the couple had 3 children- 2 boys and a girl. During the internment of Miyaji, Bujang Abdullah was 18 years old and Nongchi Abdullah was 15 and the youngest Dayang Myachi@Semah Abdullah was 13.50

On 9 January 1946, Lamah binti Bakar from Haji Taha Road in Kuching sent a petition requesting the release of her Japanese husband, Sunao Miyaji who was detained in $\mathrm{Bau}^{51}$ internment camp. ${ }^{52}$ Lamah pleaded to the authorities that her husband had nothing to do with the Japanese military during the occupation. He was working at the Dahan and Sungai Tengah rubber estates during the Japanese occupation of Sarawak. Lamah pointed to the fact that Miyaji had already lived in Sarawak for 30 years. She further concluded that Miyaji helped the Chinese and Malays when they were in trouble with the Japanese authorities. Lamah did stress that Miyaji was not in favour of the Imperial Japanese Army (IJA). ${ }^{53}$ Recognizing that Miyaji was a harmless civilian, E. A. Edmeades, SO III Kuching Police remarked that "we have no file or reports to date on this man. From indirect sources I understand that he is regarded by the public, as an old Sarawak resident. I am quite agreeable to his release." ${ }^{54}$ A good friend of Sunao Miyaji, Tuanku Bujang bin Tuanku Othman, who later became the

\footnotetext{
${ }^{47}$ Correspondence from E. Gascogine to the Police of Kuching, 30 January 1946, BBCAU Adm. K/54, Pustaka Negeri Sarawak [Sarawak State Archive], Kuching, Sarawak, Malaysia.

${ }^{48}$ Passport copy obtained from Pn. Arpah Adenan, a descendent of Miyaji who currently is serving as the Acting CEO of Pustaka Negeri Sarawak, Textual Document, Pustaka Negeri Sarawak [Sarawak State Archive], Kuching, Sarawak, Malaysia.

${ }^{49}$ Correspondence from the Ministry of Foreign Affairs Japan, kept by Pn. Arpah Adenan., Pustaka Negeri Sarawak [Sarawak State Archive], Kuching, Sarawak, Malaysia.

50 This was corroborated by Pn. Arpah Adenan.

${ }^{51} \mathrm{Bau}$ is a gold mining town in Kuching, Sarawak.

52 This was corroborated by Pn. Arpah Adenan.

${ }^{53}$ Correspondence from Lamah binti Bakar to the Police Kuching central, 9 January 194, BBCAU Adm. K/54, Pustaka Negeri Sarawak [Sarawak State Archive], Kuching, Sarawak, Malaysia.

${ }^{54}$ Correspondence from E. A. Edmeades, SO III Kuching Police to CAO (1 ${ }^{\text {st }}$ Division) Kuching, 31 January 1946. Document 39, BBCAU Adm. K/54, Pustaka Negeri Sarawak [Sarawak State Archive], Kuching, Sarawak, Malaysia.
} 
second governor of Sarawak, also tried helping by becoming a guarantor for Sunao Miyaji's release. However, a second guarantor pulled out at the last minute resulting in Miyaji being deported to Japan. ${ }^{55}$

\section{The case of Hidaka Jinosuke}

Another inter-ethnic alliance recorded was the marriage between Dayang binti Abang Wahap and Hidaka Jinonosuke, a Japanese national whom she married during the war in 1941. When Jinonosuke was detained, his daughter was 2 years old. On 5 February 1946, Dayang binti Abang Wahap sent a letter to the police station in Kuching asking for her husband to be released. Dayang petitioned by stating that her husband was a good man and never engaged in any wrongdoings. In addition, she informed the authorities that there was no one to look after her family and thus needed her Japanese husband to stay and live in Sarawak. ${ }^{56}$ Dayang also informed the British authorities that she was not willing to move to Japan. ${ }^{57}$ However, a letter by the British sent to Abang Openg stated that as Hidaka Jinonosuke was a Japanese soldier, the authorities had no choice but to deport him to Japan. At the same time, Dayang was allowed to apply to move to Japan with her Japanese husband. ${ }^{58}$

\section{The case of Maria Osaichi}

There were also inter marriages between the Japanese and local Chinese in Sarawak. The case of Maria Osaichi's assimilation into the mainstream society is particularly interesting as it involved a family member instead of her own husband, requesting her release. Like Kuno, it is believed that Osaichi was an intern in the $2^{\text {nd }}$ division prison in Seratok. On 19 November 1945, Joseph Michael Chen on behalf of Luke Chen Sen Siong sent a letter to the Kuching Division BBCAU to inform the authorities about Maria Osaichi, an elderly Japanese woman aged 60 who has been a resident of Sarawak for 30 years. Reportedly, she had never returned to Japan since her arrival in Sarawak 30 years ago. Maria Osaichi was the divorced wife of Francis Chen Ted Chong, a retired government dresser of the Medical Department in Sarawak. Joseph Michael Chen who was a clerk at the District Office in Seratok claimed that Maria Osaichi was his step-mother who had devoted herself in taking care of him since his infancy. Joseph Michael Chen requested the authorities to release Osaichi as well as grant her permission to remain as resident in Sarawak. Further he stated that if approved, she would live with Joseph Michael Chen's brother, Luke Chen Sen Siong in Pisang Road in Kuching. ${ }^{59}$ Consequently, the authorties on 20 November 1945, CAO DET BBCAU Kuching sent a letter to CAO BBCAU Simanggang regarding the request by Joseph Michael Chen to release Maria Osaichi. ${ }^{60}$ Due to insufficient documentation, it is unclear the final decision made by the authorities in the case of Maria Osaichi. However, it is believed that most Japanese immigrants in Sarawak were deported.

\footnotetext{
${ }^{55}$ Information from Pn. Arpah Adenan, Acting CEO of Pustaka Negeri Sarawak, Pustaka Negeri Sarawak [Sarawak State Archive], Kuching, Sarawak, Malaysia.

${ }^{56}$ Correspondence from Dayang binti Abang Wahap to the Police Kuching Central, 5 February 1946, BBCAU Adm. K/54, Pustaka Negeri Sarawak [Sarawak State Archive], Kuching, Sarawak, Malaysia

${ }^{57}$ Correspondence to Captain Morris CAO at BMA BB, 7 February 1946, BBCAU Adm. K/54, Pustaka Negeri Sarawak [Sarawak State Archive], Kuching, Sarawak, Malaysia.

${ }^{58}$ BBCAU Adm. K/54, Textual Document 42, Pustaka Negeri Sarawak [Sarawak State Archive], Kuching, Sarawak, Malaysia.

${ }^{59}$ Correspondence from Joseph Michael Chen and Luke Chen Sen Siong to Kuching Division BBCAU, 19 November 1945, BBCAU Adm. K/54, Pustaka Negeri Sarawak [Sarawak State Archive], Kuching, Sarawak, Malaysia.

${ }^{60}$ Correspondence from CAO DET BBCAU Kuching to CAO BBCAU Simanggang, 20 November 1945, BBCAU Adm. K/54, Pustaka Negeri Sarawak [Sarawak State Archive], Kuching, Sarawak, Malaysia.
} 


\section{The case of Oasa}

Like Maria Osaichi, another Japanese woman named Oasa was married to Law Kui Lock, the chief clerk of the Municipal Office in Kuching, more than 38 years and following the Japanese surrender in 1945, she was arrested and interned in Bidi, Upper Sarawak. ${ }^{61}$ On 27 December 1945, Teo Ek Thai from Crookshank Road, Kuching sent a letter to Captain Morris at the British Borneo Civil Affairs Unit (BBCAU) requesting the release of his Japanese aunt by the name of Oasa aged $60 .{ }^{62}$ BBCAU responded on December 28, 1945 by informing Teo Ek Thai that the question of internment of civilians is outside the jurisdiction of the BBCAU but promised the matter will be referred to higher authority. ${ }^{63}$ Once again, Ek Thai sent another letter to the British Military Administration (BMA) ${ }^{64}$ BBCAU in Kuching on January 22, 1946 requesting the release of his aunty. Further, if released, he was willing to have his Japanese aunt move in with him in Kuching. ${ }^{65}$ In response, the case was referred to the Military authorities in Labuan. ${ }^{66}$ The general consensus at that time was that most likely no Japanese civilian would be released from internment. ${ }^{67}$ Unfortunately, there were no records or follow-up sources on the fate of the appeal made by Ek Thai.

\section{RESEARCH FINDINGS}

In discussing the findings of the ongoing research, it is important to keep in mind that we are exploring a subject that has not been attempted by other scholars. The research was designed to elicit the connection between inter marriages and assimilation. The abovementioned inter-ethnic marriages showcase the extent to which Japanese migrants became assimilated into the mainstream society. In Sarawak, inter marriages between Japanese and local women seem to be small in numbers. Yet, it is an important issue to examine as they reflect the multiracial heritage of Sarawak society. Research shows that the inter-marriage assimilation is not a coherent process but more of a multidimensional process - politically, economically, socially and culturally. More significantly, the assimilation process in Sarawak seems to be absent of tension, rivalry or conflict. In fact, Japanese immigrants in Sarawak seemed to have lots of space to grow professionally and inter mingle freely with the mainstream society.

The detention of Japanese civilians and their families in internment camps has highlighted the extent to which assimilating had taken place within the broader Sarawakian society. As spouses of natives, the Japanese immersed themselves not only by simply integrating with the larger society but also in terms of economic interactions, social acculturation, and physical union. The inter-ethnic marriage became a platform for Japanese spouses to be accepted into the society. They embraced the local lifestyle and became fluent in the local language. The linguistic assimilation then allowed for

\footnotetext{
${ }^{61}$ Correspondence from Teo Ek Thai to Captain Morris BBCAU Kuching, 27 December 1945. BBCAU Adm. K/54, Pustaka Negeri Sarawak [Sarawak State Archive], Kuching, Sarawak, Malaysia.

${ }^{62}$ Correspondence from Teo Ek Thai to Captain Morris BBCAU Kuching, 27 December 1945, BBCAU Adm. K/54, Pustaka Negeri Sarawak [Sarawak State Archive], Kuching, Sarawak, Malaysia.

63 440. K/54/31, 28 December 1945, BBCAU Adm. K/54, Textual Material, BBCAU Adm. K/54, Pustaka Negeri Sarawak [Sarawak State Archive], Kuching, Sarawak, Malaysia.

${ }^{64}$ The British Military Administration (BMA) was the interim administrator of British Borneo between the end of the World War Two and the establishment of the Crown Colonies of Sarawak and North Borneo in 1946. They lasted from 12 September 1945 to 1 July 1946.

${ }^{65}$ Correspondence from Teo Ek Thai to CAO BMA BB Kuching, 22 January 1946, BBCAU Adm. K/54, Pustaka Negeri Sarawak [Sarawak State Archive], Kuching, Sarawak, Malaysia.

${ }^{66}$ Labuan became the headquarters of BMA of British Borneo.

${ }^{67}$ Correspondence from CAO BMA BB Kuching Det. To Teo Ek Thai, 31 January 1946. 36. BBCAU Adm. K/54, Pustaka Negeri Sarawak [Sarawak State Archive], Kuching, Sarawak, Malaysia
} 
further links and interaction into the local society. These spouses took pride in their new identity and respected local values and beliefs to the extent they defended them during the Japanese occupation. This is evident in the cases of Seiji Kuno and Sunao Miyaji. Kuno as an interpreter to the Japanese Imperial Army often acted as a mediator to solve problems faced by the natives during the Japanese occupation. Similarly, Sunao Miyaji also became a mediator between Japanese officials and Chinese as well as Malays.

It is not all clear if all Japanese spouses who married Malay Muslims converted to Islam. But the case of Seiji Kuno highlights how he became immersed in the religion and even gave talks and sermons to the locals about Islam. To a large extent it can be argues that religiosity shaped one's life, especially relationship with the wider community. Though religion was a conduit in the Malay community, the non-Muslim-Japanese marriages reproduced another side of the assimilation process. Japanese women who married local Chinese men became closer to the husband's extended families. This in turn created a support system for the Japanese spouse. Joseph Michael Chen's relationship with his stepmother and Teo Ek Thai's association with his aunt reflected the deep assimilation that inter marriages can make. Japanese spouses like Maria Osaichi and Oasa seem to have valued the wider kin grouping as much as individual relationships.

When World War II ended in 1945, all Japanese in Sarawak were repatriated to Japan by 1946, with the exception of a few locally-born or those permitted to stay. With so many Japanese spouses having been deported by the authorities, the issue of family reunion became unresolved. With no thought or planning of how the families might eventually be reunited, suffering and unresolved grief of those left behind in Sarawak became a reality. In the decades following the Second World War, while the older generation went through hardship and yearned to be reunited with their spouses, the younger generations became disconnected with their past. The spouse who was left behind had to adapt to facing an uncertain future. As a result of the tragedy of war and separation, it can be said that the assimilation process became severely disrupted as well as disjointed.

Despite primary data elicited from archives and secondary sources, there are concerns as it is difficult to assess the validity of the data in the traditional sense, since we relied on personal observations of British and Australian authorities about inter married couples during the incarceration of the Japanese spouse or family member. More significantly, it has been problematic to corroborate the findings simply because descendants of the inter-ethnic married couples are difficult to trace. Some are reluctant to come forward to share their knowledge about their Japanese ancestry, probably due to the deep resentment against Japan in the postwar period. Another problem that does exists is the fact that turmoil during and after World War Two has resulted in the loss of documents or photographs.

For all these reasons, only five cases of Japanese immigrants who were inter married with Sarawakians have been used as sample couples. Nonetheless the evidence is clear that inter marriages did contribute to the assimilation of foreigners into the mainstream society. During the internment of Japanese civilians, the British disregarded any form of demonstrated loyalty or assimilation that had taken place within Sarawakian society. As a result, their experiences and descendants have not only been neglected in Sarawak but also by the Japanese government. Sarawak's official documentation of its rich history of multiculturalism is void of this particular segment of minority group from its national history.

As explained before, there existed a growing Japanese population in Sarawak before the end of the Second World War. By 1901, the government designated a burial ground for the expanding community. ${ }^{68}$ Till this day, the maintenance of the graveyard is voluntarily carried out by the Japan Club of Kuching. ${ }^{6}$ With the deportation of Japanese civilians right after the Second World War, the cemetery came to disuse. ${ }^{70}$ However, the symbolic representation of the cemetery cannot be ignored. We believe that turning the Japanese cemetery as a tourist attraction is one-way Sarawakians as well

${ }^{68}$ Craig Alan Lockard, From Kampung to City: A Social History of Kuching Malaysia, 1820-1970, 38

${ }^{69}$ John M. Chin, “The Japanese Community Cemetery in Kuching," (1994): 27

${ }^{70}$ Ibid., (1994): 27. 
as Japanese nationals could reconnect with their past. The particular cemetery represents the Japanese community's history. In addition, the inscriptions and epitaphs on graves present insights into family, history as well as culture of those interred within in the Japanese cemetery.

\section{CONCLUSION}

To date the literature on intermarriages in Sarawak between Japanese nationals and native spouses is non-existent. The current research fills a small part of the existing vacuum. More efforts to reclaim Sarawak's past is necessary so that future generations are not be denied of this historical knowledge. Though neglected, it can be assumed that at least some of the descendants of the generation of locals who underwent inter-ethnic marriages would like to know the historical background behind their Japanese ancestry. Therefore, one way to further this research is to conduct oral research projects with descendants of the families that were left behind by the Japanese spouses, especially after the deportation of foreign civilians by the British. Though tracking down the descendants will be timeconsuming, but we believe that many local families are interested in reconnecting with their Japanese heritage. This study also indicates that not all Japanese in British Malaya, Sabah and Sarawak were spies to the Japanese army as perceived by most writers before. There were Japanese civilians, especially those who had assimilated successfully, who opposed Japanese military violence. In fact some of them became defenders of the local community against Japanese aggression.

\section{ACKNOWLEDGEMENT AND DECLARATION}

We would like to thank The Japan Foundation for funding the research entitled "From Medieval Malacca-Ryukyu Connections to Pre-Independence Malaysia from 2017-2020. The authors would like to show our gratitude to WIJEAS' anonymous reviewers and their constructive feedbacks in improving the quality of the manuscript. We are also immensely for their comments on earlier versions of the draft. No potential conflict of interest was reported.

\section{ARCHIVAL MATERIALS}

440. K/54/31, 28 December 1945, BBCAU Adm. K/54, Textual Material, BBCAU Adm. K/54, Pustaka Negeri Sarawak [Sarawak State Archive], Kuching, Sarawak, Malaysia.

BBCAU Adm. K/54, 11 January 1946, Textual Document, Pustaka Negeri Sarawak [Sarawak State Archive], Kuching, Sarawak, Malaysia.

BBCAU Adm. K/54, 30 January 1946, Textual Document, Pustaka Negeri Sarawak [Sarawak State Archive], Kuching, Sarawak, Malaysia.

BBCAU Adm. K/54, Textual Document 42, Pustaka Negeri Sarawak [Sarawak State Archive], Kuching, Sarawak, Malaysia.

BBCAU Adm. K/54, Textual Document, Pustaka Negeri Sarawak [Sarawak State Archive], Kuching, Sarawak, Malaysia.

Confidential document 44, BBCAU Adm. K/54, Textual Document, Pustaka Negeri Sarawak [Sarawak State Archive], Kuching, Sarawak, Malaysia.

Correspondence from Abang Openg to 7 Datus, 27 November 1945, Confidential document 43, BBCAU Adm. K/54, Pustaka Negeri Sarawak [Sarawak State Archive], Kuching, Sarawak, Malaysia.

Correspondence from Abang Openg to Captain Morris, 17 December 1945, Confidential document 56, BBCAU Adm. K/54, Pustaka Negeri Sarawak [Sarawak State Archive], Kuching, Sarawak, Malaysia. 
Correspondence from CAO BMA BB Kuching Det. To Teo Ek Thai, 31 January 1946. 36. BBCAU Adm. K/54, Pustaka Negeri Sarawak [Sarawak State Archive], Kuching, Sarawak, Malaysia.

Correspondence from CAO DET BBCAU Kuching to CAO BBCAU Simanggang, 20 November 1945, BBCAU Adm. K/54, Pustaka Negeri Sarawak [Sarawak State Archive], Kuching, Sarawak, Malaysia.

Correspondence from Cao Det BBCAU Kuching to the HQ "K" Force Kuching, 29 October 1945, Pustaka Negeri Sarawak [Sarawak State Archive], Kuching, Sarawak, Malaysia.

Correspondence from Dayang binti Abang Wahap to the Police Kuching Central, 5 February 1946, BBCAU Adm. K/54, Pustaka Negeri Sarawak [Sarawak State Archive], Kuching, Sarawak, Malaysia

Correspondence from DET BBCAU Kuching sent to HQ Force Kuching, 12 October 1945, BBCAU Adm. K/54, Pustaka Negeri Sarawak [Sarawak State Archive], Kuching, Sarawak, Malaysia.

Correspondence from DET BBCAU Kuching sent to HQ Force Kuching, 29 October 1945, Pustaka Negeri Sarawak [Sarawak State Archive], Kuching, Sarawak, Malaysia.

Correspondence from E. A. Edmeades, SO III Kuching Police to CAO (1 ${ }^{\text {st }}$ Division) Kuching, 31 January 1946. Document 39, BBCAU Adm. K/54, Pustaka Negeri Sarawak [Sarawak State Archive], Kuching, Sarawak, Malaysia.

Correspondence from E. Gascogine to the Police of Kuching, 30 January 1946, BBCAU Adm. K/54, Pustaka Negeri Sarawak [Sarawak State Archive], Kuching, Sarawak, Malaysia.

Correspondence from Joseph Michael Chen and Luke Chen Sen Siong to Kuching Division BBCAU, 19 November 1945, BBCAU Adm. K/54, Pustaka Negeri Sarawak [Sarawak State Archive], Kuching, Sarawak, Malaysia.

Correspondence from Lamah binti Bakar to the Police Kuching central, 9 January 194, BBCAU Adm. K/54, Pustaka Negeri Sarawak [Sarawak State Archive], Kuching, Sarawak, Malaysia.

Correspondence from Major T. A. Rodriquez, BM Kuching Force, 28 November 1945, Pustaka Negeri Sarawak [Sarawak State Archive], Kuching, Sarawak, Malaysia.

Correspondence from Teo Ek Thai to CAO BMA BB Kuching, 22 January 1946, BBCAU Adm. K/54, Pustaka Negeri Sarawak [Sarawak State Archive], Kuching, Sarawak, Malaysia.

\section{REFERENCES}

Chin, John M., “The Japanese Community Cemetery in Kuching," Sarawak Gazette 121, no. 1527, (1994): 19-28.

Digby, K. H., Lawyer in the Wilderness, (New York: Cornell University, 1980).

Fujio, Hara, "Japanese Activities in North Borneo Before World War II: Focus on Labour Immigrants," Sejarah: Journal of the Department of History 29, no. 2, (I993): 123-146.

Gin, Ooi Keat, Rising Sun Over Borneo: The Japanese Occupation of Sarawak, 1941-1945, (London: Macmillan Press Ltd., 1999).

Gin, Ooi Keat, The Japanese Occupation of Borneo, 1941-1945, (London: Routledge, 2011).

Gordon, Milton M., Assimilation in American Life: The Role of Race, Religion, and National Origins, (New York: Oxford University Press, 1964).

Ho, Ah Chon, Kuching in Pictures, 1841-1946, (Kuching: See Hua Daily News Bhd., 1965).

Kaur, Amarjit, "The Babbling Brookes: Economic Change in Sarawak 1841-1941," Modern Asian Studies 29, no. 1, (I995): 65-109.

Lockard, Craig Alan, From Kampung to City: A Social History of Kuching Malaysia, 1820-1970, (Athens, Ohio: Ohio University Press, 1987).

Marcson, Simon, "A Theory of Intermarriage and Assimilation," Social Forces 29, no. 1 (1950): 7578. 
Md Akhir, Md Nasrudin, dan Tsuji Shyuji, "Aktiviti Ekonomi dan Pertubuhan Orang Jepun di Selangor, 1881-1931," dalam Rohayati Paidi, Asmadi Hassan, dan Md Nasrudin Md Akhir eds., Jepun dan Dinamisme Global, (Kuala Lumpur: UM Press, 2019), 3-25

Montero, Darrel, "The Japanese Americans: Changing Patterns of Assimilation Over Three Generations," American Sociological Review 46, no. 6, (1981): 829-839.

Noakes, J. L., Sarawak and Brunei: A Report on the 1947 Population Census, (Kuching: Government Printing Press, 1950).

Pei, Chen Shick, "Coal Potential and Exploration in Sarawak," Bulletin of the Geological Society of Malaysia 20, no. August, (1986): 649-665.

Price, C. A. and J. Zubrzycki, "The Use of Inter-Marriage Statistics as an Index of Assimilation," Population Studies 16, no. 1 (1962): 58-69.

Qian, Zhenchao and Daniel T. Lichter, "Social Boundaries and Marital Assimilation: Interpreting Trends in Racial and Ethnic Intermarriage," American Sociological Review 72, no. 1, (2007): 6894.

Reece, Bob, Masa Jepun: Sarawak under the Japanese 1941-1945, (Kuala Lumpur: Sarawak Literacy Society, 1998). 